Wojciech Skiba

ORCID: 0000-0003-3809-1035

Uniwersytet Wrocławski

\title{
Przyczyny i efekty zmian w polskiej polityce społecznej wobec osób niepełnosprawnych w latach 1991-2017
}

DOI: $10.19195 / 1643-0328.25 .2$

Słowa kluczowe: polityka społeczna, osoby niepełnosprawne, problemy społeczne, sprawność instytucji

\section{Wprowadzenie}

Niniejszy artykuł stanowi próbę identyfikacji przyczyn kluczowych zmian w polskiej polityce społecznej wobec osób niepełnosprawnych. Obszar ten cechuje się zmiennością na poziomie rozwiązań szczegółowych i względnie dużą trwałością kluczowych rozwiązań systemowych. Wskazując na ciągłość rozwiązań, należy zauważyć, iż geneza wielu $\mathrm{z}$ nich sięgała jeszcze poprzedniego systemu społeczno-gospodarczego.

Istotną cechą polskiej polityki w tym obszarze jest fragmentaryzacja działań. Zarówno współczesna literatura przedmiotu, jak i praktyka działania wskazują, iż do najważniejszych warunków realizacji efektywnego wsparcia dla osób z niepełnosprawnością należą jego kompleksowość i indywidualizacja. Te cechy utożsamia się często z implementacją do polityki społecznej niektórych założeń tzw. społecznego modelu niepełnosprawności ${ }^{1}$, czy też podejmowaniem prób implementacji rozwiązań charakterystycznych dla modelu funkcjonalnego, opartego przede wszystkim na doświadczeniach różnych krajów związanych z wdrażaniem systemów opierających się na Międzynarodowej Klasyfikacji ICF². Odmienne, niezintegrowane podejście traktowane jest jako wskaźnik stosowania przez państwo przestarzałych i nieadekwatnych do występujących problemów form udzielania wsparcia. Problem ten porusza m.in. B. Gonciarz, mówiąc o konieczności prawnego ugruntowania działań związanych ze społecznym modelem niepełnosprawności jako

${ }^{1}$ Por. M. Wliński, Modele niepetnosprawności: indywidualny - funkcjonalny - społeczny, [w:] A. Brzezińska, R. Kaczan, K. Smoczyńska, Diagnoza potrzeb i modele pomocy dla osób z ograniczeniami sprawności, Warszawa 2010, s. 50-56.

2 ICF. Międzynarodowa Klasyfikacja Funkcjonowania, Niepełnosprawności i Zdrowia, Warszawa 2010. 
warunku zauważalnego podniesienia efektywności działań państwa w tym obszarze ${ }^{3}$. Zarówno ustawa o rehabilitacji z 1991 r. ${ }^{4}$, jak i kolejna, z roku 1997, stanowiąca jej rozwinięcie ${ }^{5}$, w dużej mierze służyły dostosowaniu ukształtowanego w okresie PRL systemu rehabilitacji do nowych warunków ustrojowych. Zamiast, zgodnie ze współczesnym im podejściem, być wyrazem tworzenia holistycznej polityki, stanowiły wręcz krok wstecz w zakresie rehabilitacji kompleksowej, w stosunku do wcześniejszych rozwiązań. Pomimo definiowania, przez drugą z wyżej wskazanych ustaw, zjawiska niepełnosprawności poprzez pryzmat możliwości pełnienia przez daną osobę funkcji społecznych, w praktyce ten najważniejszy dla niepełnosprawnych akt prawny abstrahuje od wielu bardzo istotnych wymiarów życia społecznego i związanych $\mathrm{z}$ nimi ról społecznych ${ }^{6}$. Mimo to ustawa o rehabilitacji stanowi swoisty „silosowy rdzeń” polskiej polityki społecznej wobec osób niepełnosprawnych, w ramach którego strony publiczna i społeczna od lat poszukują takich formuł działania, które efektywniej rozwiązywałyby diagnozowane problemy osób niepełnosprawnych.

\section{Metodologia}

Z uwagi na przyjęty zakres analizy, obejmujący zmiany w polskiej polityce społecznej wobec osób niepełnosprawnych, uznano, że podstawowym wskaźnikiem tych zmian są akty prawa krajowego, w szczególności ustawy. Do 1999 r. administracja państwowa była $\mathrm{w}$ zasadzie jedynym podmiotem odpowiedzialnym za realizację polityki w tym obszarze. Następnie część kompetencji przejęła, w związku z wdrażaniem drugiego etapu decentralizacji państwa, administracja samorządowa (powiaty i województwa samorządowe). Jednakże oba wymienione szczeble samorządu posiadały bardzo ograniczone kompetencje w zakresie kreowania polityki. Ustawodawca przewidział dla nich rolę realizatorów polityki przy pomocy odgórnie określonych, mało elastycznych instytucji. W praktyce działania te sprowadzały się do realizacji ściśle określonych zadań z zakresu ustawy o rehabilitacji (np. dofinansowania likwidacji barier architektonicznych czy turnusów rehabilitacyjnych) według kryteriów, które zostały ściśle określone na poziomie rozporządzeń do rzeczonej ustawy. $Z$ tego względu zasadne wydaje się przyjęcie, iż determinujący wpływ na kształt polityki w tym względzie miało ustawodawstwo. $Z$ powyższego względu najwłaściwszą metodą badania tej problematyki jest wtórna analiza danych zastanych, w postaci ustaw i uzasadnień, oraz ocena skutków regulacji. Uwzględniając uchwalanie ustaw oraz aktów zmieniających te ustawy, w omawianym w artykule okresie

3 B. Gąciarz, Model społeczny niepelnosprawności jako podstawa zmian w polityce społecznej, [w:] Polscy niepetnosprawni, red. B. Gąciarz, S. Rudnicki, Kraków 2014, s. 17-41.

${ }^{4}$ Ustawa z dnia 9 maja 1991 r. o zatrudnieniu i rehabilitacji zawodowej osób niepełnosprawnych, Dz.U. z 1991, nr 46, poz. 201.

${ }^{5}$ Ustawa z dnia 27 sierpnia 1997 r. o rehabilitacji zawodowej i społecznej oraz zatrudnianiu osób niepełnosprawnych, Dz.U. z 1997, nr 123, poz. 776.

${ }^{6}$ Ibidem. 
otrzymamy łączną liczbę 11 nowelizacji ustawy z 1991 r. i 85 nowelizacji ustawy z 1997 oraz odpowiednio 11 i 168 legislacji dotyczących przepisów wykonawczych ${ }^{7}$.

Na potrzeby artykułu analizą objęto ustawy o rehabilitacji z roku 1991 i 1997 oraz ustawy powiązane z nimi w zakresie modyfikacji i kreowania najważniejszych instytucji konstytuujących ten obszar polityki publicznej (np. część ustaw podatkowych). Przeglądowi poddano także procedowane przez parlament projekty zmian w ww. ustawach, traktując je jako wskaźnik swoistej gry interesów prowadzonych wokół kwestii reform systemu. Ich analiza stanowiła często dobrą ilustrację gry interesów podmiotów zaangażowanych w realizację polityki państwa wobec osób niepełnosprawnych. W związku z przyjętą perspektywą teoretyczną, postrzegającą problematykę zmian w polityce społecznej w kategoriach ewolucji instytucji przez ciągłość oraz zależności od przebytego szlaku, konieczne było uwzględnienie aktów prawnych konstytutywnych dla tego obszaru polityki w okresie PRL. Ścieżka zależności rozumiana jest jako określone dziedzictwo instytucji, a więc czynnik ciągłości społeczeństwa (np. instytucja chronionego zatrudnienia), ale także jako ograniczone pole zmian wynikające $\mathrm{z}$ toczącej się w obrębie tych instytucji gry interesów poszczególnych grup ${ }^{8}$. Wydaje się, że bez przyjęcia perspektywy instytucjonalno-historycznej niemożliwe jest zrozumienie kształtu wielu kluczowych instytucji wprowadzonych ustawami z lat 1991 i 1997, a zwłaszcza fenomenu trwałości niektórych z nich pomimo, często oczywistych, dowodów na ich bardzo niską efektywność w odniesieniu do osiągania oficjalnie głoszonych celów polityki, do których od lat w tym obszarze należy np. stały wzrost poziomu zatrudnienia osób niepełnosprawnych. Zależność od szlaku uwidaczniająca się jako odporność na zmiany wydaje się być bardzo dobrze zauważalna i została częściowo przełamana dopiero w obliczu konieczności wprowadzania niezbędnych zmian będących warunkiem koniecznym wejścia do Unii Europejskiej ${ }^{9}$. Za kluczową uznano analizę tych instytucji, które miały służyć realizacji strategicznych celów polityki (przede wszystkim rehabilitację i zatrudnienie niepełnosprawnych). Część tych instytucji, jak wpłaty pracodawców z tytułu niezatrudniania pracowników niepełnosprawnych, stanowi stały element systemu od wejścia w życie ustawy o rehabilitacji z 1991 r., inne, jak np. zwolnienia podatkowe pracodawców, obecnie mają znaczenie marginalne, jednak do czasu wejścia Polski do UE stanowiły one podstawę systemu wsparcia przedsiębiorców. Posługując się kryteriami ilościowymi, na podstawie analizy wykonania budżetów państwa, w tym w szczególności planu finansowego PFRON (udział w generowaniu odpowiednio: przychodów i wydatków), zaliczyć do nich można:

- PFRON jako podmiot organizujący proces poboru środków finansowych oraz ich dystrybucję;

7 Dane za: https://sip.lex.pl/\#/act/16798906/2239902/rehabilitacja-zawodowa-i-spoleczna-oraz-zatrudnianie-osob-niepelnosprawnych?keyword=ustawa\%20o\%20rehabilitacji\&cm=SREST (dostęp: 2.11.2017).

8 D.C. North, Zrozumieć przemiany gospodarcze, Warszawa 2014, s. 54-56.

9 Więcej na temat wprowadzenia wspólnych zasad w obszarze polityki ochrony konkurencji, które zlikwidowały bądź zredefiniowały w zasadzie wszystkie instytucje wspierania zatrudnienia osób niepełnosprawnych przewidziane ustawą o rehabilitacji: W. Skiba, Wplyw instytucji pomocy publicznej na instrumenty polityki społecznej w obszarze aktywizacji zawodowej osób niepełnosprawnych, [w:] Instytucje $w$ teorii i praktyce, red. B. Borkowska, Wrocław 2015, s. 213-237. 
- w obszarze przychodów systemu: wpłaty z tytułu niezatrudniania osób niepełnosprawnych, które stanowiły w zależności od roku od ok. dwóch trzecich do ponad trzech czwartych całości przychodów funduszu ${ }^{10}$; zwolnienia i ulgi podatkowe trafiające w większości bezpośrednio do beneficjentów systemu oraz dotacje budżetowe do wybranych zadań z ustawy o rehabilitacji;

- w obszarze wydatkowania środków: zwolnienia i ulgi podatkowe, subwencje i dofinansowania do zatrudnienia osób niepełnosprawnych, przelewy redystrybucyjne na realizację zadań samorządu terytorialnego;

— instytucje, których pojawienie się uznać można za istotne dla zmiany w modelu prowadzonej polityki, a więc charakterystyczne dla funkcjonalnego lub społecznego definiowania problemu niepełnosprawności.

Jednocześnie z racji mnogości instytucji, dużej liczby zmian w zasadach ich funkcjonowania, a także bardzo ograniczonego miejsca niniejsza analiza $\mathrm{z}$ pewnością nie wyczerpuje całości tematu poruszanego w artykule. Nie stanowi także w żadnej mierze wyczerpującego indeksu tych zmian. Częściowy brak chronologii w analizie przypadków zmian $\mathrm{w}$ polityce wynika $\mathrm{z}$ zastosowania ujęcia problemowego.

\section{Geneza instrumentów i instytucji systemu rehabilitacji osób niepełnosprawnych — źródło dobrych inspiracji i późniejszych problemów $\mathbf{w}$ realizacji polityki}

Charakter zmian $\mathrm{w}$ tym obszarze koresponduje $\mathrm{w}$ znacznej mierze $\mathrm{z}$ ich kierunkiem $\mathrm{w}$ innych obszarach polskiej polityki społecznej, w pewnym zakresie wykazuje także własną specyfikę. Elementy podobieństwa wynikają przede wszystkim z ogólnych, przyjętych np. w Konstytucji RP, zasad ustrojowych i polityki społecznej poszczególnych rządów po roku 1989. Te wspólne zasady, które odciskały piętno na rozwiązaniach dedykowanych osobom niepełnosprawnym, to z pewnością dążenie do ciągłości instytucjonalnej i dostosowania rozwiązań sprzed 1989 r. do wymogów nowego ładu społeczno-ekonomicznego ${ }^{11}$. Jednocześnie omawiany obszar cechuje się znaczną specyfiką na tle pozostałych polityk społecznych. Najważniejszą cechą wydaje się być dalece posunięta prywatyzacja zadań publicznych, która cechowała ten obszar już od chwili uchwalenia ustawy z 1991 r., a która paradoksalnie stanowiła logiczną konsekwencję przyjętej w polskiej polityce społecznej zasady dążenia do zachowania ciągłości rozwiązań i wdrażania działań dostosowujących te instrumenty do zmienionych warunków otoczenia $^{12}$. I tak PRL-owski spółdzielczy monopol na realizację zadań z zakresu rehabilitacji zawodowej zastąpiony został rynkowym pluralizmem form własności, jednak przy zachowaniu monopolu środowisk gospodarczych na realizację zadań z zakresu

10 Na podstawie sprawozdań z realizacji planu finansowego PFRON za lata 1999-2016.

11 Por. E. Karpowicz, Modele polityki społecznej. Kierunki zmian polityki społecznej w Polsce, Informacja BSiE nr 1249 (IP-111S) s. 3-10, http://biurose.sejm.gov.pl/teksty_pdf_06/i-1249.pdf (dostęp: 4.04.2017).

12 Ibidem. 
rehabilitacji zawodowej, aż do czasów rozpoczęcia tworzenia zakładów aktywności zawodowej (ZAZ), które jednak w ograniczonym zakresie wypełniały zakładane cele ${ }^{13}$. Rolą Państwowego Funduszu Rehabilitacji Osób Niepełnosprawnych (PFRON), funduszu celowego utworzonego na mocy ustawy z 1991 r., było gromadzenie środków i finansowanie, w oparciu o nie, zadań z zakresu rehabilitacji zawodowej i społecznej. Zależność od wcześniejszych rozwiązań instytucjonalnych i ukształtowanych m.in. pod ich wpływem zasobów bardzo mocno rzutowała na kształt polskiej polityki aż do $2004 \mathrm{r}^{14}$ Później jej wpływ ulegał szybszemu zanikowi pod wpływem procesów konwergencji z UE.

Dokonywana przez osoby niepełnosprawne ocena systemu wsparcia wypada dla polskiej polityki społecznej nie najlepiej. O ile przyjmiemy, za A. Kurzynowskim, iż działalność instytucji państwa powinna kształtować takie warunki funkcjonowania członków społeczeństwa, aby przy danych realiach gospodarczych zapewnić jak najlepsze i najbardziej sprawiedliwe zaspokajanie potrzeb ${ }^{15}$, o tyle w oczach tychże obywateli ocena osiąganych efektów na przestrzeni ostatnich 25 lat pozostawia wiele do życzenia. Jak pisze A. Ostrowska ${ }^{16}$, ocena ta jest znacznie gorsza niż ocena systemu wsparcia w czasach PRL. W badaniach z 1993 i 2013 jedynie 3\% badanych niepełnosprawnych oceniło wsparcie państwa jako wystarczające dla tej kategorii osób, a w 1978 r. taką ocenę wystawiało aż $37 \%$ badanych ${ }^{17}$. Rzetelność odpowiedzi udzielanych w badaniach sondażowych w okresie PRL może budzić pewne wątpliwości, ale analiza funkcjonowania spółdzielni inwalidów do 1990, a następnie ZPCh po wprowadzeniu nowych przepisów wskazuje, iż te pierwsze, także $\mathrm{z}$ wskazanych $\mathrm{w}$ dalszej części artykułu przyczyn, lepiej wywiązywały się z obowiązków dotyczących rehabilitacji leczniczej i społecznej pracowników, niż robiły to nowe podmioty zaangażowane w zatrudnienie chronione od $1991 \mathrm{r}$. Skłania to do pytania: dlaczego pomimo setek zmian w ustawach i rozporządzeniach i wydawaniu rok rocznie wielu miliardów złotych społeczny odbiór prowadzonej polityki pozostaje relatywnie zły?

\section{Charakterystyka przyczyn zmian w polityce państwa względem osób niepełnosprawnych — próba typologii}

Na podstawie analizy ustaw o rehabilitacji z 1991 i 1997 i aktów zmieniających te ustawy oraz przepisów dotyczących rehabilitacji osób niepełnosprawnych z okresu PRL, a także dostępnych uzasadnień wprowadzanych zmian w przepisach prawa można zaproponować

13 Temat współdziałania różnych instytucji dedykowanych aktywizacji i rehabilitacji zawodowej wymaga odrębnej analizy. Wskazaną problematyczną efektywność ekonomiczną i społeczną ZAZ wykazał raport Zakłady Aktywności Zawodowej. Raport z badania, Warszawa 2009.

14 J. Dzionek-Kozłowska, Transformacja ustrojowa z perspektywy koncepcji path dependence, „Prace Naukowe Uniwersytetu Ekonomicznego we Wrocławiu. Ekonomia" 2009, nr 3, s. 213-227.

15 A. Kurzynowski, Osoby niepetnosprawne w polityce społecznej, [w:] J. Mikulski, J. Auleytner, Polityka społeczna wobec niepetnosprawnych. Droga do integracji, Warszawa 1996.

16 A. Ostrowska, Niepetnosprawni w społeczeństwie, Warszawa 2014, s. 236-242.

17 Ekspertyza na temat sytuacji osób niepełnosprawnych i stanu rehabilitacji w PRL, za: ibidem, s. 240. 
następującą klasyfikację najważniejszych przyczyn dokonywania zmian, w tym reform polityki społecznej wobec osób niepełnosprawnych:

- wynikające ze zmiany systemu społeczno-gospodarczego, wymuszającej działania dostosowawcze tego obszaru polityki;

- związane z zachwianiem stabilności finansowej systemu oraz usuwające diagnozowane dysfunkcje i patologie;

— związane z działaniami dostosowawczymi do wspólnych polityk Unii Europejskiej;

- towarzyszące decentralizacji zadań państwa;

- związane z rzecznictwem interesów realizatorów zadań z zakresu rehabilitacji zawodowej;

- stanowiące próby zmiany paradygmatu polityki w tym obszarze.

Powyższa typologia stanowi oczywiście uproszczenie genezy zmian, które stosunkowo rzadko wynikały z jednej, dającej się prosto sklasyfikować przyczyny.

\section{Zmiany w polityce jako przejaw procesów dostosowawczych do zmian ustrojowych}

Pierwszą reformą związaną z tym czynnikiem było uchwalenie ustawy o rehabilitacji z 1991 r. Jej pierwotna nazwa, pod którą zgłoszono projekt do prac parlamentarnych ustawa o rehabilitacji inwalidów w procesie pracy, wskazuje na związek proponowanych rozwiązań z instytucjami poprzedniego systemu, które w momencie procedowania tejże ustawy stanowiły w zasadzie jedyny funkcjonujący element systemu aktywizacji osób niepełnosprawnych. Bezpośrednią przyczyną reformy była konieczność wykreowania nowych mechanizmów finansowania zatrudnienia osób niepełnosprawnych w obliczu zakwestionowania w warunkach wolnego rynku mechanizmu funkcjonowania opartego o monopole i przywileje produkcyjne i usługowe ${ }^{18}$.

Podstawową wartością, jaką usiłowano przenieść w nowe warunki społeczno-gospodarcze, była zasada rehabilitacji kompleksowej, w której kluczową rolę podmiotu dostarczającego niezbędnego wsparcia i je koordynującego odgrywał pracodawca funkcjonujący w ramach specjalnego statusu zakładu pracy chronionej. Dawać miał on gwarancję dostarczania pracownikowi wsparcia adekwatnego do jego niepełnosprawności. Dzięki temu po roku 1991 segregacyjny system zatrudnienia stał się na długie lata podstawową, w odróżnieniu od krajów Europy Zachodniej, formą rehabilitacji zawodowej osób niepełnosprawnych. Jednocześnie ustawa z $1991 \mathrm{r}$. wprowadzała do polskiej polityki społecznej nowe instytucje, których kształt i zasady działania wzorowane były na rozwiązaniach funkcjonujących od lat w krajach UE. Kształt części tych instytucji, takich jak Pełnomocnik Rządu do spraw Osób Niepełnosprawnych, rady konsultacyjne czy rada nadzorcza PFRON, po części wiązał się z rozwijającym się społecznym podejściem do problematyki niepełnosprawności.

18 Uchwała Rady Ministrów z 13 grudnia 1973 w sprawie zapewnienia warunków dalszego rozwoju spółdzielczości inwalidów, M.P. z 1973, nr 56, poz. 314. 
Oceniając z perspektywy czasu dokonaną reformę, stwierdzić należy, iż była ona konieczną odpowiedzią na wyzwania czasu, ale nie okazała się ona wystarczająca. Do pozytywnych aspektów reformy zaliczyć możemy:

- zapewnienie stabilnych źródeł finansowania wydatków na realizację zadań z zakresu rehabilitacji społecznej i zawodowej;

- rozwój nowych form wsparcia, powolną implementację do polskiego systemu rozwiązań bazujących na najlepszych praktykach z zakresu rehabilitacji społecznej;

- korzystne, sprzyjające rozwojowi firm, głównie posiadających status ZPCh, rozwiązania.

Negatywnie natomiast należy ocenić:

- oparcie instrumentów polityki na segregacyjnych formach wsparcia;

- brak integracji działań z zakresu różnych form rehabilitacji, skutkujący fragmentaryzacją oddziaływań i niską efektywnością społeczną i ekonomiczną (np. rugowanie $\mathrm{z}$ rynku pracy osób z najcięższymi niepełnosprawnościami) ${ }^{19}$;

- brak efektywnych narzędzi kontroli i ewaluacji instrumentów polityki społecznej, skutkujący ponoszeniem przez sektor finansów publicznych kosztów nieadekwatnie wysokich w stosunku do prowadzonych działań;

- źle funkcjonujący system orzekania o niepełnosprawności (funkcja bramy wejściowej do systemu wsparcia) oparty o kryteria medyczne, a nie funkcjonalne;

- stagnację poziomu zatrudnienia osób niepełnosprawnych na relatywnie niskim poziomie (ryc. 1 i 2);

- utrzymującą się fragmentaryzację polityki społecznej względem osób niepełnosprawnych (brak realizacji deklarowanej rehabilitacji kompleksowej), pomimo istnienia funkcji koordynującej (Pełnomocnik Rządu) ${ }^{20}$.

\section{Przywracanie stabilności finansowej systemu i reakcja na zdiagnazowane patologie jako główna przyczyna wdrażania reform polityki}

Powierzenie prywatnym podmiotom gospodarczym realizacji najważniejszych celów polityki państwa związanych z rehabilitacją zawodową stanowiło silną pokusę osiągania przez przedsiębiorców dodatkowych korzyści z tego tytułu. Umożliwiał to brak ewaluacji i kontroli stosowania instrumentów polityki i tym samym brak działań korygujących system wsparcia zatrudnienia. Jednym ze źródeł takiego stanu był lobbing środowiska pracodawców osiągających niewspółmierne korzyści w stosunku do realizowanych zadań publicznych oraz wciąż słaba artykulacja interesów osób niepełnosprawnych ${ }^{21}$. Próby ewaluacji instrumentów systemu wsparcia podjęła się po raz pierwszy NIK, diagnozując

19 Porównaj np. B. Gąciarz, op. cit.; W. Bąbka, Analiza i ocena polskiego systemu zatrudnienia osób $z$ niepelnosprawnościami, Kraków 2015.

20 B. Gąciarz, op. cit.

21 W. Skiba, op. cit. 
wiele bardzo poważnych patologii stawiających pod znakiem zapytania funkcjonowanie instrumentów rehabilitacji zawodowej ${ }^{22}$.

Nowelizacje ustawy o rehabilitacji z 1997, która w pierwotnym kształcie utrzymała, a miejscami rozbudowała system przy wilejów związanych z zatrudnieniem osób niepełnosprawnych w stosunku do ustawy z 1991 r., stopniowo ograniczyły skalę dysproporcji pomiędzy ponoszonymi kosztami związanymi z zatrudnianiem osób niepełnosprawnych a otrzymywanym wsparciem.

Przykładem działań racjonalizujących system była m.in. nowelizacja z września $1999 \mathrm{r}$. wydłużająca czas, po jakim prowadzący zakład mógł ubiegać się o status ZPCh. Zgodnie z nowymi przepisami podmiot taki musiał istnieć minimum rok, a wymagany wskaźnik zatrudnienia musiał być osiągnięty i utrzymywany przez minimum pół roku przed nadaniem statusu ZPCh. Zmiana ta wynikała z lawinowo rosnącej liczby ZPCh i wiedzy kręgów rządowych, iż nowo tworzone podmioty nie koniecznie nastawiały się na realizację celów polityki państwa, lecz korzystając z luk w systemie, realizowały cele stricte gospodarcze ${ }^{23}$. Potwierdza to uzasadnienie projektu ustwawy. Zgodnie z nim ustawodawca chciał doprowadzić do sprawdzania, czy nowo zakładane, a także istniejące już zakłady spełniają wymogi wskazane w ustawie o rehabilitacji, w tym czy realnie funkcjonują i faktycznie zatrudniają niepełnosprawnych ${ }^{24}$. Dalej idące propozycje zmian, które mogłyby przyczynić się do bardziej efektywnej realizacji celów polityki państwa, także wskutek zwiększenia nadzoru nad środkami publicznymi, nie znajdowały wystarczającego wsparcia, by wprowadzono je w życie. Przykładem może być projekt nowelizacji ustawy o rehabilitacji z grudnia 1999 r. Uzasadnienie projektu zawiera ocenę funkcjonowania najważniejszych instrumentów. Negatywnie ocenione zostały skutki mechanizmu sankcyjnego, który nie przekładał się na wzrost zatrudnienia osób niepełnosprawnych na otwartym rynku pracy. Podobna ocena dotyczy ZPCh z wyjątkiem spółdzielni. Dostrzega się, iż część ich właścicieli zorientowana jest na osiąganie korzyści finansowych, a nie na prowadzenie rehabilitacji. Celem nowelizacji miała być taka modyfikacja systemu, która wymusiłaby zwiększenie zatrudnienia osób niepełnosprawnych i jednocześnie doprowadziła do likwidacji tzw. kominów we wsparciu niektórych pracodawców, poprzez wprowadzenie górnych limitów odliczeń i powiązanie ich ze stopniem niepełnosprawności. Projekt zgodny z interesami osób niepełnosprawnych nie został jednak uchwalony ${ }^{25}$.

22 Informacja o wynikach kontroli tworzenia i utrzymania miejsc pracy dla osób niepetnosprawnych ze środków Państwowego Funduszu Rehabilitacji Osób Niepelnosprawnych, Warszawa 1999, s. 16-17.

23 Informacja o wynikach kontroli gospodarowania zakładowym funduszem rehabilitacji w ZPCH, Łódź 2003, s. 3-38.

24 Projekt ustawy o zmianie ustawy o rehabilitacji zawodowej i społecznej oraz zatrudnieniu osób niepełnosprawnych, druk sejmowy nr 1330/1999, Sejm III kad., http://orka.sejm.gov.pl/Rejestrd.nsf/ wgdruku/1330/\$file/1330.pdf (dostęp: 7.05.2017); projekt ustawy o zmianie ustawy o rehabilitacji zawodowej i społecznej oraz zatrudnieniu osób niepełnosprawnych, druk sejmowy nr 1462, s. 32-37, Sejm III kad., http://orka.sejm.gov.pl/Rejestrd.nsf/wgdruku/1462/\$file/1462.pdf (dostęp: 11.05.2017).

25 Projekt ustawy o zmianie ustawy o rehabilitacji zawodowej i społecznej oraz zatrudnieniu osób niepełnosprawnych, druk sejmowy nr 1669, Sejm III kad., http://orka.sejm.gov.pl/Rejestrd.nsf/ wgdruku/1669/\$file/1669.pdf (dostęp: 11.05.2017). 
Ilustracją wskazywanych m.in. przez NIK patologii, związanych przede wszystkim $\mathrm{z}$ brakiem związku pomiędzy wielkością zatrudnienia osób niepełnosprawnych oraz wysokością uzyskiwanej pomocy publicznej na ich zatrudnienie w formie bezpośrednich subwencji oraz ulg i zwolnień podatkowych, mogą być rozwierające się nożyce pomiędzy procentowym przyrostem liczby ZPCh a procentowym wzrostem liczby zatrudnionych przez te zakłady pracowników niepełnosprawnych.

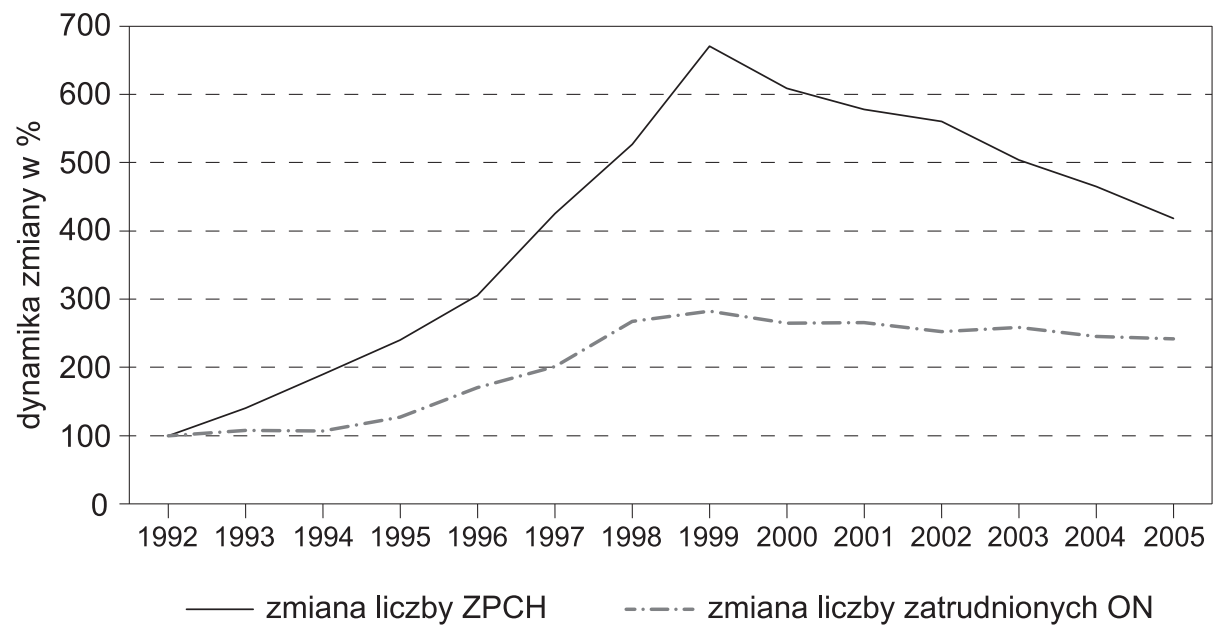

Rycina 1. Zmiana liczby ZPCh i zatrudnianych przez nie osób niepełnosprawnych

Źródło: www.mpips.gov.pl/userfiles/File/BON.

Kolejnym przykładem może być nowelizacja ustawy o rehabilitacji z końca 2000 r., której celem było przede wszystkim podniesienie efektywności ściągania wpłat obowiązkowych na PFRON. We wcześniejszym o rok przedłożeniu nie zauważono, iż jedną z przyczyn niskiego wskaźnika zatrudnienia na otwartym rynku pracy jest możliwość „nieujawniania się" w bazach PFRON jako podmiot zobowiązany do wpłat. Aż do czasu uchwalenia ww. noweli PFRON nie miał instrumentów prawnych do weryfikowania swojej bazy płatników ${ }^{26}$. Skutkowało to relatywnie niską ściągalnością wpłat obowiązkowych, a także brakiem identyfikacji wielu potencjalnych płatników ${ }^{27}$. W późniejszym okresie sprawność instytucji w tym względzie uległa istotnej poprawie, także dzięki współpracy z ZUS, a poziom ściągalności nie odbiegał istotnie od innych tego typu podmiotów, osiągając w ostatniej dekadzie wartości powyżej $99 \%{ }^{28}$.

Problem konieczności uszczelnienia systemu orzekania dla celów pozarentowych, w związku z dokumentowanymi coraz częstszymi przypadkami uzyskiwania orzeczeń przez osoby zdrowe oraz wywieraniem wpływu na komisje orzekające przez pracodaw-

26 Projekt ustawy o zmianie ustawy o rehabilitacji zawodowej i społecznej oraz zatrudnieniu osób niepełnosprawnych, druk sejmowy nr 2264, Sejm III kad., http://orka.sejm.gov.pl/Rejestrd.nsf/ wgdruku/2264/\$file/2264.pdf (dostęp: 11.05.2017).

27 Kwestię tę analizuje m.in. W. Bąbka, op. cit., s. 130.

28 https://bip.pfron.org.pl/pfron/budzet-funduszu/ (dostęp: 12.05.2017). 
ców, pojawia się w procedowaniu nowelizacji z listopada $2001 \mathrm{r}$. Wprowadził on wiele zmian poprawiających nadzór nad orzekaniem i utrudniających manipulację tą procedurą, np. poprzez podniesienie wymogów dla członków komisji orzekających; wynikało to z diagnozy, iż niedostateczne kompetencje jej członków są źródłem niskiej jakości orzekania $^{29}$.

Liczne zmiany dokonywane pod szyldem racjonalizacji wydatków publicznych nie wynikały z analizy efektywności systemu, lecz jedynie z bieżącego salda przychodów i wydatków na zadania przewidziane ustawą. Wzrost tzw. wydatków sztywnych ponad możliwości finansowania ich w oparciu o bieżące przychody powodował konieczność zmiany prawa i ograniczanie wydatków na zadania ustawowe. Przykładem zmian wynikających z konieczności utrzymania bądź przywrócenia stabilności finansowej systemu może być nowelizacja z 1 stycznia 2004 r., nad którą prace rozpoczęły się dopiero w grudniu 2003 r. W uzasadnieniu przedłożenia stwierdza się wprost, iż zmiana wynika $\mathrm{z}$ konieczności ograniczenia deficytu finansów publicznych, ograniczenia dotacji budżetu państwa dla PFRON. Brak wzmianek o wpływie zmiany na realizację celów, w szczególności sytuację osób niepełnosprawnych. W ocenie skutków regulacji zawarto informację o negatywnej ocenie projektu przez partnerów społecznych i braku wpływu na rynek pracy ${ }^{30}$, co może wskazywać na niską efektywność systemu przed zmianą.

Podobny projekt z lipca 2010 r. dotyczył zapobieżenia utracie płynności finansowej przez PFRON ${ }^{31}$. Uchwalona na jego podstawie ustawa odbierała od 2011 r. dofinansowania pracodawcom na zatrudnienie osób niepełnosprawnych, które nabyły prawo do emerytury, z wyjątkiem osób ze znacznym stopniem niepełnosprawności. O braku przemyślanej polityki w tym obszarze świadczyć może fakt, iż ustawodawca niewiele wcześniej, od 1 stycznia 2009 r., rozszerzył możliwość pobierania dofinansowania na wskazaną kategorię osób.

\section{Reformy wynikające z procesu integracji i akcesji Polski do Unii Europejskiej}

Kolejnym przykładem zmian reformujących omawiany obszar polityki społecznej i mających charakter działań dostosowawczych były zmiany wynikające $z$ harmonizacji polskiego prawa z prawem unijnym. Wskazany przykład jest tym bardziej ciekawy, iż co do

29 Projekt ustawy o zmianie ustawy o pomocy społecznej, ustawy o planowaniu rodziny, ochronie płodu ludzkiego i warunkach dopuszczalności przerywania ciąży, ustawy o rehabilitacji zawodowej i społecznej oraz zatrudnianiu osób niepełnosprawnych, druk sejmowy nr 66, Sejm IV kad., http://orka.sejm.gov.pl/ Druki4ka.nsf/wgdruku/66/\$file/66.pdf (dostęp: 11.05.2017).

30 Rządowy projekt ustawy o zmianie ustawy o rehabilitacji zawodowej i społecznej oraz zatrudnieniu osób niepełnosprawnych, druk sejmowy nr 2292, s. 13, Sejm IV kad., http://orka.sejm.gov.pl/Druki4ka. nsf (dostęp: 12.05.2017).

31 Poselski projekt ustawy o zmianie ustawy o rehabilitacji zawodowej i społecznej oraz zatrudnieniu osób niepełnosprawnych i niektórych innych ustaw, druk sejmowy nr 3292, Sejm VI kad., http://orka.sejm. gov.pl/proc6.nsf/opisy/3292.htm (dostęp: 12.05.2017). 
zasady polityka społeczna stanowi, niepodlegającą ujednoliceniu, domenę państw członkowskich. W przypadku Polski bardzo istotna część instytucji i instrumentów polityki w tym obszarze pochodziła ze sfery polityki fiskalnej i gospodarczej, zaliczanych przez UE do pomocy publicznej dla przedsiębiorców, podlegającej w UE ścisłej harmonizacji. Podjęcie działań dostosowawczych stanowiło dla Polski warunek konieczny zakończenia negocjacji akcesyjnych i przyjęcia w poczet państw członkowskich. Zmiany te w momencie ich uchwalania nie były postrzegane, ani przez ustawodawcę, ani przez większość partnerów społecznych, jako pozytywny czynnik reformujący polską politykę, lecz jako zagrożenie realizacji jej celów. Z tego powodu ciekawe może być wskazanie wpływu tych zmian na efektywność społeczną i ekonomiczną systemu rehabilitacji. Działania dostosowawcze po wejściu w życie 1 lutego 1994 układu stowarzyszeniowego pomiędzy Polską a UE były wyjątkowo powolne i nie wpływały istotnie na kształt polityki społecznej. Pierwszym krokiem, dotyczącym zresztą wszelkich polityk, w ramach których udzielano wsparcia przedsiębiorcom, było rozpoczęcie monitoringu pomocy publicznej. Jednakże model monitoringu był mocno niedoskonały i nie obejmował większości zwolnień podatkowych, jakimi cieszyły się zakłady pracy chronionej. Zaryzykować można tezę, iż był to obszar, który dość istotnie mógł spowalniać proces integracji Polski z UE. Próby zmian systemu wsparcia dla pracodawców zatrudniających osoby niepełnosprawne, w związku z koniecznością sprostania wymogom unijnym, uległy intensyfikacji od 1999 r., jednak $\mathrm{w}$ dalszym ciągu spotykały się z oporem. Przykładem siły wpływu ze strony podmiotów zainteresowanych utrzymaniem dotychczasowych rozwiązań były nieudane działania legislacyjne, np. projekty nowelizacji z $1999 \mathrm{r}^{32}$, w których uzasadnieniu stwierdza się wprost, że obecnie funkcjonujący system zwolnień jest niezgodny z prawodawstwem UE. Można stwierdzić, iż aż do 2000 r. zobowiązania układu stowarzyszeniowego nie wpływały na kształt polityki w zakresie wspierania pracodawców osób niepełnosprawnych w Polsce i hamowały proces przygotowywania akcesji do UE.

Postęp w zakresie dostosowania prawodawstwa do wymogów UE przyniosło dopiero uchwalenie i wejście w życie ustawy o pomocy publicznej ${ }^{33}$, która wstrzymała znaczną część wsparcia na zatrudnienie osób niepełnosprawnych. Od 1 stycznia 2001 r. Urząd Ochrony Konkurencji i Konsumentów stał się organem zatwierdzającym pomoc udzielaną na cele związane z rehabilitacją zawodową. Aspekt społeczny wsparcia, np. na utrzymanie zagrożonych likwidacją miejsc pracy w ZPCh, z którego często korzystały spółdzielnie inwalidów, stał się wtórny względem oceny zgodności wsparcia wynikającego z prawa unijnego.

32 Rządowy projekt ustawy o zmianie ustawy o rehabilitacji zawodowej i społecznej oraz zatrudnieniu osób niepełnosprawnych oraz ustawy o podatku od towarów i usług i ustawy o podatku dochodowym, druk sejmowy nr 1462 i 1462A, Sejm III kad., http://orka.sejm.gov.pl/proc3.nsf/0/3BD262AD568B26A3C 1257456004D47AA?OpenDocument (dostęp: 12.05.2017).

33 Ustawa z dnia 30 czerwca 2000 r. o warunkach dopuszczalności i nadzorowaniu pomocy publicznej dla przedsiębiorców, Dz.U. z 2000, nr 60, poz. 704. 
Uznanie, z chwilą akcesji do UE, za niedopuszczalne tzw. pomocy automatycznej wymusiło kolejne zmiany dostosowawcze i zastąpienie, wcześniej już postulowane przez reformatorów systemu, zwolnień podatkowych subwencjami płacowymi uzależnionymi od stopnia i rodzaju niepełnosprawności. Implementacja kolejnego rozporządzenia Komisji Europejskiej w 2008 r. spowodowała obniżenie maksymalnego wsparcia z tytułu zatrudnienia ze $100 \%$ do maksymalnie $75 \%$ kosztów pracy. Należy uznać to za symboliczną datę, od której pomoc państwa na zatrudnienie osób niepełnosprawnych po raz pierwszy od 1991 r. nie mogła przekroczyć kosztów zatrudnienia danej osoby.

W ramach dostosowania prawa zmodyfikowano także definicję osoby niepełnosprawnej w ustawie o rehabilitacji, kładąc większy nacisk na niezdolność do pełnienia ról społecznych jako warunek umożliwiający udzielanie wsparcia w ramach form zaliczanych do pomocy publicznej, co w polskich warunkach stanowiło blisko trzy czwarte środków przeznaczanych na finansowanie polityki w tym obszarze. Regulacje unijne bowiem jasno wskazywały na możliwość adresowania wsparcia wyłącznie do osób, których stan zdrowia uniemożliwia normalne funkcjonowanie, wykluczając tym samym osoby, których stan tylko utrudnia pełnienie ról społecznych, co wcześniej dopuszczał polski system ${ }^{34}$. W odniesieniu do wpływu na efektywność realizowanej polityki stwierdzić należy, iż na podstawie danych zawartych w cytowanym powyżej projekcie ustawy do objęcia wsparciem na zatrudnienie, w myśl definicji unijnej, kwalifikować powinno się ok. 32\% pracowników (ZPCh zatrudniały wówczas 3,1\% osób ze znacznym i $29 \%$ z umiarkowanym stopniem, co odpowiadało kryteriom unijnym). Pozostałe $68 \%$ pracowników posiadało orzeczenie o stopniu lekkim, co według kryteriów UE oznaczało, iż co do zasady nie powinny być objęte wsparciem na zatrudnienie $\mathrm{w}$ formie stałych subsydiów ${ }^{35}$.

Podsumowując zmiany polityki wynikające z procesu integracji europejskiej, stwierdzić należy, iż przy okazji osiągnięto istotne rezultaty niezamierzone. Wiązały się one z zawartą implicite w rozwiązaniach unijnych racjonalnością ekonomiczną i społeczną, wyrażoną np. zasadą, iż całkowita wartość wsparcia na zatrudnienie osoby niepełnosprawnej nie może być wyższa od kosztów wynikających z zatrudniania tej osoby. Efektem harmonizacji prawa było więc, postulowane dużo wcześniej, zlikwidowanie „kominów” we wsparciu, jakie otrzymali pracodawcy osób niepełnosprawnych. Pomimo spadku przysporzeń dla pracodawców w przeliczeniu na jednego zatrudnionego pracownika wskaźnik zatrudnienia niepełnosprawnych w wieku aktywności zawodowej po roku 2004 nie tylko nie malał, ale nawet wzrósł o kilka punktów procentowych, co obrazuje poniższy wykres.

34 Rządowy projekt ustawy o zmianie ustawy o rehabilitacji zawodowej i społecznej oraz zatrudnieniu osób niepełnosprawnych oraz ustawy o podatku od towarów i usług i ustawy o podatku dochodowym..., s. 45 .

35 Niepetnosprawność a praca w Polsce, Warszawa 2000, s. 6-16. 


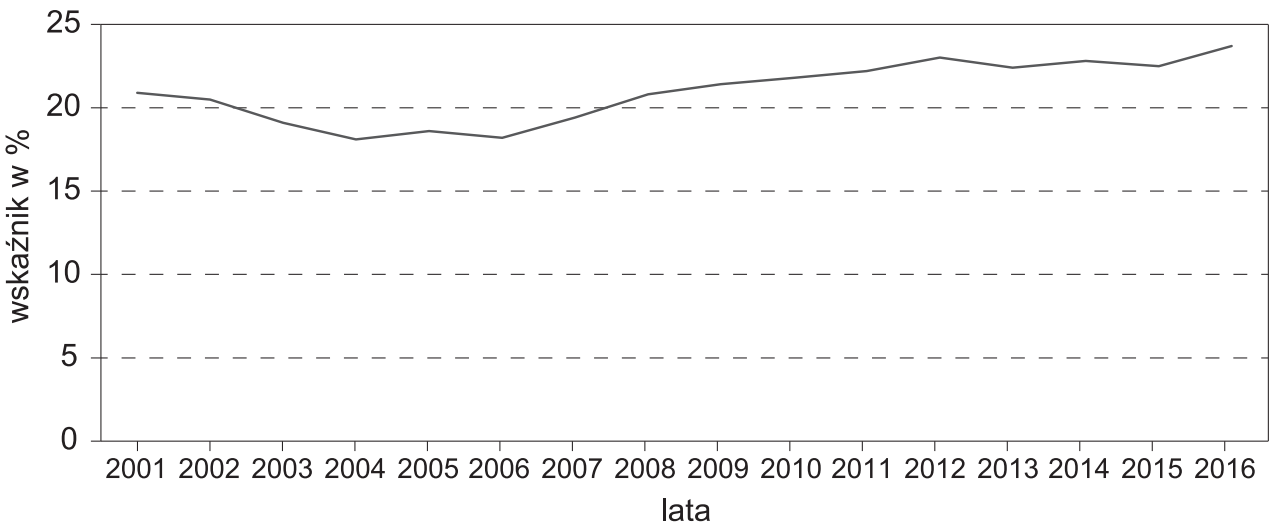

Rycina 2. Wskaźnik zatrudnienia osób niepełnosprawnych w wieku produkcyjnym (dane BAEL) Źródło: Badanie Aktywności Ekonomicznej Ludności, GUS.

\section{Reformy decentralizujące politykę społeczną względem osób niepełnosprawnych}

W ramach reformy ustrojowej państwa, wdrażanej od 1999 r., dokonano decentralizacji realizacji części zadań będących dotąd w gestii administracji państwowej. Zostały one przekazane do realizacji nowo tworzonym szczeblom samorządu terytorialnego. Przekazanie zadań realizowanych przez PFRON było logiczną konsekwencją zmian ustrojowych i było zgodne z konstytucyjną zasadą pomocniczości. Reformę tę możemy, z jednej strony, traktować jako zmianę dostosowawczą do zmieniającego się ładu ustrojowego, który nakazuje decentralizację zadań i realizację ich „bliżej obywatela”, z drugiej — jako wyraz reform zorientowanych na potrzeby osób niepełnosprawnych. Wydaje się jednak, że czynnikiem przeważającym było działanie dostosowawcze. Świadczy o tym to, że przy okazji tej zmiany ustrojowej i przekazywaniu kompetencji na lokalnie zorientowany poziom administracji nie dokonano przeglądu efektywności instrumentów wsparcia i nie wprowadzono adekwatnych zmian.

Oceniając pozytywnie decentralizcję zadań, zwrócić należy uwagę na liczne mankamenty wdrożonej reformy, które w zasadzie utrzymują się do dziś. Największą wadą wdrożonego rozwiązania było zbyt ścisłe określenie możliwych do realizacji zadań, które sumarycznie nie realizowały postulatu prowadzenia rehabilitacji kompleksowej jako warunku efektywnej rehabilitacji. Postulat rehabilitacji kompleksowej, pomimo braku explicite wyrażonego sformułowania w prawie, stale przewija się w uzasadnieniach projektów zmian i dyskusjach publicznych. Ponadto enumeratywne wyliczenie listy możliwych do realizacji zadań, które mogły być finansowane ze środków PFRON, zdejmowało z samorządu odpowiedzialność za rezultat procesu rehabilitacji, sprowadzając jego działania do finansowania zleconych ustawą tutułów. W przypadku instrumentów wsparcia 
adresowanych bezpośrednio do osób niepełnosprawnych, takich jak np. dofinansowanie do likwidacji barier architektonicznych, skróceniu uległa droga do uzyskania wsparcia, co dla osób niepełnosprawnych było w części usprawiedliwione. Jednak ścisłe określenie instrumentów wsparcia i określenie w rozporządzeniach dokładnych form realizacji tych zadań spowodowało ubezwłasnowolnienie samorządów i brak możliwości efektywnego tworzenia lokalnych programów działań na rzecz osób niepełnosprawnych, uwzględniających specyficzne potrzeby osób niepełnosprawnych na danym terenie, a ich tworzenie było i jest przecież przewidziane prawem ${ }^{36}$.

\section{Zmiany związane z rzecznictwem interesów realizatorów zadań z zakresu rehabilitacji zawodowej}

W latach 90. XX w., a także w pierwszych latach XXI w. możliwości realizacji celów polityki w obszarze rehabilitacji wiązano $\mathrm{z}$ finansowanymi ze środków publicznych działaniami pracodawców. Rozwiązania pozytywnie oceniane przez środowisko pracodawców uznawano często automatycznie za korzystne dla osób niepełnosprawnych. Po kilku latach funkcjonowania systemu, wraz z pierwszymi informacjami z szeroko zakrojonych kontroli NIK, pojawiły się jednak wątpliwości, czy to, co korzystne dla środowisk pracodawców, jest dobre dla osób niepełnosprawnych. Problem ten dotyczył przede wszystkim zakładów pracy chronionej, których przedstawiciele wywierali istotny wpływ na uchwalenie obu ustaw o rehabilitacji, wchodząc w rolę kontynuatorów uształtowanego w czasach PRL systemu rehabilitacji. Istotnym lobby, któremu udawało się forsować zmiany przeciwskuteczne do celów polityki w obszarze rehabilitacji, było także środowisko pracodawców sektora publicznego. Przykładem zmiany będącej efektem lobbingu pracodawców osób niepełnosprawnych może być nowelizacja ustawy o rehabilitacji z 1998 liberalizująca wymogi dotyczące minimalnej liczby pracowników takich zakładów z 40 do 20 osób. Projekt tej ustawy powstał w komisji małych przedsiębiorstw ${ }^{37}$ i odwołuje się jedynie do argumentów leżących po stronie przedsiębiorców, pomijając ich specjalny status i rolę podmiotów realizujących politykę społeczną państwa w obszarze rehabilitacji, a także zupełnie abstrahując od wielkości środków publicznych, jakie te przedsiębiorstwa przejmują na realizację zadań związanych z rehabilitacją zawodową, a także w części społeczną i leczniczą zatrudnionych osób niepełnosprawnych. Na lobbingowy charakter ustawy wskazuje jej uzasadnienie, w którym stwierdza się, iż ustawa

${ }^{36}$ Zob. W. Skiba, Wsparcie dla osób niepelnosprawnych $w$ powiatowych strategiach rozwiązywania problemów społecznych: efektywna pomoc w rehabilitacji, czy przypadkowo dobrane działania?, [w:] Niepelnosprawność i starość, red. M. Halicka, J. Halicki, J. Borowik, Białystok 2016, s. 117-135 (= „Pogranicze. Studia społeczne" 28).

37 Komisyjny projekt ustawy o zmianie ustawy o rehabilitacji zawodowej i społecznej oraz zatrudnieniu osób niepełnosprawnych, druk sejmowy nr 366, Sejm III kad., http://orka.sejm.gov.pl/Rejestrd.nsf/ wgdruku/366/\$file/366.pdf (dostęp: 13.05.2017). 
nie pociąga za sobą konsekwencji dla budżetu państwa. Tymczasem ustawa zapobiegała zaostrzeniu kryteriów uzyskania bądź utrzymania statusu ZPCh, który to status wiązał się w owym czasie z ustanowionymi ustawą o rehabilitacji bardzo dużymi przywilejami finansowymi. Niezgodność procedowanej ustawy z celami polityki społecznej dostrzegł Senat, stwierdzając, iż inicjatywa legislacyjna wynika tylko i wyłącznie z interesów przedsiębiorców i nie ma nic wspólnego z interesem pracowników niepełnosprawnych ${ }^{38}$. Stanowisko Senatu nie zostało jednak uwzględnione przez Sejm.

Innym przykładem zmian w polityce, które uznać należy za przeciwskuteczne względem założonych celów, było wprowadzenie liberalnych, w stosunku do innych podmiotów gospodarki narodowej, wymogów w zakresie zatrudniania osób niepełnosprawnych przez szkoły wyższe. W praktyce skutkowało to zwolnieniem ich z kar z tytułu niezatrudniania niepełnosprawnych. Nowelizacja wprowadziła do ustawy o rehabilitacji nowe, znacznie niższe wskaźniki zatrudnienia pracowników niepełnosprawnych dla szkół wyższych. Alternatywnym rozwiązaniem do zatrudnienia i tak nieznacznego odsetka niepełnosprawnych było kształcenie studentów z niepełnosprawnościami, których wymagany odsetek wynosił początkowo jedynie $0,1 \%$ ogółu studentów ${ }^{39}$. W uzasadnieniu czytamy, iż zwolnienie szkół wyższych z wpłat przy osiągnięciu tych niskich wskaźników będzie sprzyjało tworzeniu szkolnictwa integracyjnego. Na poziomie uzasadnienia projektu ustawy odnotować należy brak jakiejkolwiek analizy, wskazującej na konieczność tak drastycznej redukcji celów polityki państwa w tym obszarze rynku pracy i traktowania go inaczej niż innych sektorów zatrudnienia. Zmiana została wprowadzona.

\section{Próby zmiany paradygmatu polityki. Reformy polityki realizujące prawa osób niepełnosprawnych}

Argument, iż realizowana polityka społeczna w zbyt małym stopniu dotyczy osób niepełnosprawnych, a w zbyt dużym różnych podmiotów mających działać na ich rzecz, pojawia się w debacie publicznej niemalże od chwili uchwalenia pierwszej ustawy o rehabilitacji. Wyrazem troski o właściwe priorytety polityki było uchwalenie w 1997 Karty praw osób niepełnosprawnych. W ślad za tym dokumentem uchwalono nową ustawę o rehabilitacji zawodowej i społecznej oraz zatrudnieniu osób niepełnosprawnych. W stosunku do ustawy z $1991 \mathrm{r}$. ustawodawca wprowadza mechanizmy partycypacji społecznej zarówno w sferze kreowania polityki państwa w tym obszarze (Krajowa Rada Konsultacyjna do spraw Osób Niepełnosprawnych), jak i w obszarze realizowania polityki państwa: Rada Nadzorcza PFRON posiada, wbrew nazwie, także kompetencje merytoryczne. Dodat-

${ }^{38}$ Komisyjny projekt ustawy o zmianie ustawy o rehabilitacji zawodowej i społecznej oraz zatrudnieniu osób niepełnosprawnych, opinia senatu, druk sejmowy nr 477, Sejm III kad., http://orka.sejm.gov. pl/Rejestrd.nsf/wgdruku/477/\$file/477.pdf (dostęp: 15.05.2017).

39 Komisyjny projekt ustawy o zmianie ustawy o rehabilitacji zawodowej i społecznej oraz zatrudnieniu osób niepełnosprawnych, druk sejmowy nr 1059, Sejm III kad., http://orka.sejm.gov.pl/proc3.nsf/ opisy/1059.htm (dostęp: 15.05.2017). 
kowo reforma samorządowa z 1999 r. ustanawia analogiczne ciała społeczne, w postaci powiatowych i wojewódzkich rad do spraw osób niepełnosprawnych, w samorządzie. Oceniając pierwszy etap procesu uspołecznienia polityki społecznej wobec osób niepełnosprawnych, wskazać można na pewne niewątpliwe sukcesy; największym było stworzenie instytucjonalnych mechanizmów artykulacji interesów tych środowisk. Zwłaszcza dla problemów niezwiązanych bezpośrednio z kwestią zatrudnienia, określanych zbiorczo jako rehabilitacja społeczna, była to pierwsza zinstytucjonalizowana forma wyrażania opinii i artykułowania postulatów.

Przez wiele lat wskaźnikiem uwzględniania głosów środowiska w bieżącej realizacji polityki społecznej względem osób niepełnosprawnych był procentowy wskaźnik wydatków na działania $\mathrm{z}$ zakresu rehabilitacji społecznej, w kontrze do wydatków na rehabilitację zawodową. Wzrost wydatków z tej pierwszej kategorii w stosunku do drugiej odczytywany był jako postęp w kierunku urzeczy wistnienia postulatów tych środowisk, a spadek jako regres. $\mathrm{W}$ istocie na przestrzeni lat relacje tych kategorii wydatków zmieniały się względem siebie zwykle nieznacznie i trudno uchwycić w tych zmianach jakąkolwiek tendencję. Zwykle określone zmiany $\mathrm{w}$ tych wydatkach miały związek $\mathrm{z}$ koniecznością zbilansowania budżetu ${ }^{40}$. Istotną zmianą z punktu widzenia oceny priorytetów rządu w polityce na rzecz osób niepełnosprawnych było podpisanie przez Polskę w 2006 Konwencji ONZ o prawach osób niepełnosprawnych, a także modelowanie instrumentów polskiej polityki społecznej przez wzorce zawarte w wielu unijnych politykach horyzontalnych, obliagoryjnych przy wydatkowaniu środków pochodzących z UE, które powoli zaczęły przenikać do reguł wsparcia regulujących wydatkowanie środków krajowych. Wydaje się jednak, że pierwszoplanowe znaczenie miała narastająca presja ze strony coraz bardziej aktywnych środowisk osób niepełnosprawnych ${ }^{41}$. Rosnąca presja skutkowała wzrostem budżetów PFRON i samorządów dla organizacji pozarządowych, a także ograniczaniem przywilejów ZPCh na rzecz premiowania zatrudnienia osób z najcięższymi niepełnosprawnościami w ramach innych instrumentów, jak np. zakłady aktywności zawodowej. Dobrym wskaźnikiem tej tendencji jest wzrost liczby osób zatrudnionych w ZAZ, które w przeciwieństwie do ZPCh prowadziły rehabilitację osób z najcięższymi niepełnosprawnościami ${ }^{42}$.

${ }^{40}$ Na podstawie: Sprawozdania finansowe z realizacji planu działalności, planu finansowego PFRON za lata 1998-2016.

41 Przykładem mogą być masowe demonstracje osób niepełnosprawnych w Warszawie w latach 20122014: http://warszawa.wyborcza.pl/warszawa/1,34889,14200250,Manifestacja_kilku_tysiecy_gluchych_i_ niewidomych.html oraz https://www.wprost.pl/kraj/438000/Manifestacja-osob-gluchych-w-Warszawie5-tys-uczestnikow.html (dostęp: 12.05.2017).

42 Procentowy udział osób niepełnosprawnych ze znacznym stopniem niepełnosprawności wśród ogółu pracowników ZPCh pozostawał niższy niż na otwartym rynku pracy, na co wskazują dane PFRON z systemu obsługi dofinansowania i rejestru podmiotów potencjalnie zobowiązanych do wpłat na PFRON (deklaracje DEK). Dopiero presja na rozwijanie przewidzianych przepisami prawa instytucji dedykowanych stricte takim osobom spowodowała przeznaczanie środków PFRON będących w gestii samorządów wojewódzkich na tworzenie ZAZ. 


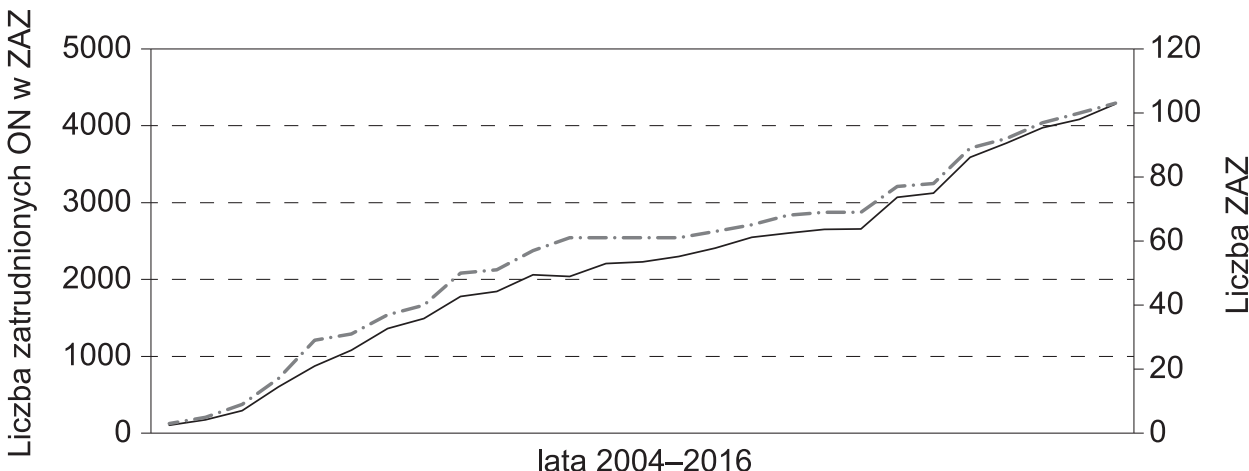

— liczba zatrudnionych ON -.--- ilość funkcjonujących ZAZ

Rycina 3. Wzrost liczby ZAZ i pracujących w nich osób niepełnosprawnych

Źródło: PFRON.

Ratyfikacja w 2012 r. przez parlament Konwencji o prawach osób niepełnosprawnych, w przeciwieństwie do podpisanej przez Polskę wcześniej konwencji Międzynarodowej Organizacji Pracy w sprawie osób niepełnosprawnych, dała silny bodziec do dalszych zmian w prawie w kierunku wdrażania rozwiązań zgodnych ze społecznym podejściem do kwestii niepełnosprawności. Konwencja stała się nośną platformą aktywizacji środowisk osób niepełnosprawnych i stanowiła wzmocnienie nacisku tego środowiska na przyśpieszenie reform polityk publicznych, stając się punktem odniesienia do oceny jakości polskiego systemu wsparcia. Sprzyjały temu bardzo nośne społeczne wartości, na których opiera się konwencja, takie jak: poszanowanie przyrodzonej godności i autonomii osoby, brak dyskryminacji, pełny udział w społeczeństwie, równość szans, dostępności, poszanowanie odmienności i ich szczegółowe rozwinięcie w dalszych częściach tego dokumentu ${ }^{43}$. W efekcie po raz pierwszy od $1991 \mathrm{r}$. działania reformujące politykę społeczną w tym zakresie zaczęły być prowadzone z perspektywy praw i potrzeb osób niepełnosprawnych. Wydaje się, iż taką ocenę uprawnia szereg podjętych działań legislacyjnych:

- uchwalenie przepisów stymulujących podmioty publiczne do zwiększenia zatrudnienia osób niepełnosprawnych, w szczególności poprzez zmiany w Prawie Zamówień Publicznych, które umożliwiły uzyskanie pewnych preferencji dla podmiotów zatrudniających osoby niepełnosprawne w procedurach ubiegania się o zamówienie publiczne zgodnie z trybami ustawy;

- zmiana ustawy o służbie cywilnej i niektórych innych ustaw wprowadzająca preferencje w zatrudnianiu osób niepełnosprawnych na stanowiskach urzędniczych, w przypadku gdy dany urząd administracji publicznej nie wypełnia wskaźnika zatrudnienia z ustawy o rehabilitacji;

- przyjęcie ustawy o dostosowaniu wyborów do potrzeb osób niepełnosprawnych to akt prawny, gdzie podmiotem działań są osoby niepełnosprawne, a nie różne instytucje

43 Ustawa z dnia 15 czerwca 2012 r. o ratyfikacji Konwencji o prawach osób niepełnosprawnych, sporządzonej w Nowym Jorku dnia 13 grudnia 2006 r., art. 3, Dz.U. z 2012, poz. 882. 
mające realizować cele polityki państwa; ustawa zakładała scalenie, rozproszonych dotąd $\mathrm{w}$ trzech aktach prawnych, uprawnień wyborczych osób niepełnosprawnych i istotne ich poszerzenie w stosunku do osób z umiarkowaną i znaczną niepełnosprawnością; zakładała też umożliwienie głosowania korespondencyjnego, wprowadzone zostały nakładki w języku Braille’a na karty wyborcze;

- uchwalenie ustawy o języku migowym, wprowadzającej szereg ułatwień komunikacyjnych dla osób głuchych, w tym, dzięki nadaniu językowi migowemu statusu języka urzędowego, umożliwiającej tym osobom załatwianie spraw w instytucjach publicznych;

- nowelizacja ustawy o rehabilitacji zwanej „ustawą o psie przewodniku"44;

- przyjęcie ustawy o tzw. racjonalnym dostosowaniu, zmieniającej ustawę o rehabilitacji, zgodnie z którą pracodawca jest obowiązany zapewnić niezbędne racjonalne usprawnienia dla osoby niepełnosprawnej; niezbędne racjonalne usprawnienia polegają na przeprowadzeniu koniecznych w konkretnej sytuacji zmian lub dostosowań do szczególnych potrzeb, o ile przeprowadzenie takich zmian lub dostosowań nie skutkowałoby nałożeniem na pracodawcę nieproporcjonalnie wysokich obciążeń ${ }^{45}$.

\section{Podsumowanie}

Ocena przyczyn zmian polskiego prawa w obszarze wsparcia dla osób niepełnosprawnych wymyka się jednoznacznym interpretacjom. Do czasu, gdy konieczne stało się dostosowanie wielu kluczowych jej instytucji do wymogów stawianych przez akcesję Polski do Unii Europejskiej, najważniejsze modyfikacje w obrębie tego obszaru polityki, dotyczące takich instytucji, jak zwolnienia podatkowe czy różne formy subsydiowania pracodawców posiadających status ZPCh, przebiegały zgodnie z logiką „zależności od szlaku", wykazując silną oporność na zmiany istotne z punktu widzenia innych grup interesów, np. środowisk osób niepełnosprawnych. Najważniejszą kwestią, ogniskującą debatę, było odejście od nadmiarowych przywilejów, które udało się uzyskać środowisku ZPCh, przy uchwalaniu przepisów dostosowujących wcześniejsze rozwiązania systemowe do warunków gospodarki wolnorynkowej oraz przy wprowadzaniu nowych, zaczerpniętych z zachodnioeuropejskich systemów instytucji, takich jak opłata sankcyjna z tytułu niezatrudniania czy PFRON jako fundusz celowy służący prowadzeniu polityki państwa w obszarze rehabilitacji. Dostosowano tym samym te nowe instrumenty polityki do dotychczasowej „logiki” systemu i sprawiono, że służyły one przede wszystkim osiąganiu korzyści przez dominujące dotychczas grupy interesu. Punkt zwrotny w polityce społecznej wobec osób niepełnosprawnych stanowi z pewnością wejście Polski do Unii Europejskiej. Oznaczało to, wymuszony przez czynnik zewnętrzny, koniec nadmiarowych przywilejów, których symbolem była wysokość subwencji płacowych na jednego

44 Ustawa z dnia 21 listopada 2008 r. o zmianie ustawy o rehabilitacji zawodowej i społecznej oraz zatrudnianiu osób niepełnosprawnych, ustawy o podatkach i opłatach lokalnych oraz ustawy o bezpieczeństwie żywności i żywienia, Dz.U. z 2008, nr 223, poz. 1463.

45 Ustawa z dnia 3 grudnia 2010 r. o wdrożeniu niektórych przepisów Unii Europejskiej w zakresie równego traktowania, Dz.U. z 2010, nr 254, poz. 1700; z 2013, poz. 675; z 2015, poz. 1268; z 2016, poz. 691. 
pracownika uzyskiwana przez ZPCh, przekraczająca, często bardzo znacznie, całkowite koszty wynagrodzenia. Dzięki tej zmianie w systemie uwolnione zostały środki finansowe na inne działania, takie jak tworzenie alternatywnych form rehabilitacji zawodowej dla osób z najcięższymi niepełnosprawnościami (np. ZAZ), a także, jak to wykazano w powyższej analizie, jakościowe zmiany w przedmiocie działań legislacyjnych parlamentu. Tworzone ustawodawstwo było skoncentrowane wokół problemów środowiska osób z poszczególnymi niepełnosprawnościami, a nie wokół problemów narzucanych przez wcześniej ukształtowane lobby środowisk gospodarczych, jak to było w zdecydowanej większości inicjatyw legislacyjnych do roku 2004.

\section{Bibliografia}

Bąbka W., Analiza i ocena polskiego systemu zatrudnienia osób z niepetnosprawnościami, Wyd. UE, Kraków 2015.

Brzezińska A., Kaczan R., Smoczyńska K., Diagnoza potrzeb i modele pomocy dla osób z ograniczeniami sprawności, Wyd. Nauk. Scholar, Warszawa 2010.

Dzionek-Kozłowska J., Transformacja ustrojowa z perspektywy koncepcji path dependence, „Prace Naukowe Uniwersytetu Ekonomicznego we Wrocławiu. Ekonomia” 2009, nr 3, s. 213-227.

Gąciarz B., Model społeczny niepetnosprawności jako podstawa zmian w polityce społecznej, [w:] Polscy niepetnosprawni, red. B. Gąciarz, S. Rudnicki, AGH, Kraków 2014, s. 17-41.

Gorajewska D., Społeczeństwo równych szans. Tendencje i kierunki zmian. Integracja, Warszawa 2005.

Gordat M., Rehabilitacja zawodowa i zatrudnienie chronione osób z niepełnosprawnościami w Polsce geneza, rozwój i stan obecny, „Niepełnosprawność” 2015, nr 1 (14).

ICF. Międzynarodowa Klasyfikacja Funkcjonowania, Niepelnosprawności i Zdrowia, WHO, wyd. polskie CSIOZ, Warszawa 2010.

Informacja o wynikach kontroli gospodarowania zakładowym funduszem rehabilitacji osób niepetnosprawnych w zakładach pracy chronionej, NIK, Łódź 2003.

Informacja o wynikach kontroli systemu rehabilitacji zawodowej osób niepelnosprawnych, NIK, Warszawa 2001.

Informacja o wynikach kontroli tworzenia i utrzymania miejsc pracy dla osób niepełnosprawnych ze środków Państwowego Funduszu Rehabilitacji Osób Niepetnosprawnych, NIK, Warszawa 1999.

Karpowicz E., Modele polityki społecznej. Kierunki zmian polityki społecznej w Polsce, Informacja BSiE nr 1249 (IP-111S) s. 3-10, http://biurose.sejm.gov.pl/teksty_pdf_06/i-1249.pdf (dostęp: 4.04.2017).

Komisyjny projekt ustawy o zmianie ustawy o rehabilitacji zawodowej i społecznej oraz zatrudnieniu osób niepełnosprawnych, druk sejmowy nr 366, Sejm III kad., http://orka.sejm.gov.pl/Rejestrd.nsf/ wgdruku/366/\$file/366.pdf (dostęp: 13.05.2017).

Komisyjny projekt ustawy o zmianie ustawy o rehabilitacji zawodowej i społecznej oraz zatrudnieniu osób niepełnosprawnych, opinia senatu, druk sejmowy nr 477, Sejm III kad., http://orka.sejm.gov.pl/Rejestrd. nsf/wgdruku/477/\$file/477.pdf (dostęp: 15.05.2017).

Komisyjny projekt ustawy o zmianie ustawy o rehabilitacji zawodowej i społecznej oraz zatrudnieniu osób niepełnosprawnych, druk sejmowy nr 1059, Sejm III kad., http://orka.sejm.gov.pl/proc3.nsf/opisy/1059. htm (dostęp: 15.05.2017).

Kozek W., Rynek pracy. Perspektywa instytucjonalna, Wydawnictwo Uniwersytetu Warszawskiego, Warszawa 2013.

Kurzynowski A., Osoby niepetnosprawne w polityce społecznej, [w:] J. Mikulski, J. Auleytner, Polityka społeczna wobec niepetnosprawnych. Droga do integracji, WSP TWP, Warszawa 1996. 
Mikulski J., Auleytner J., Polityka społeczna wobec niepetnosprawnych. Droga do integracji, WSP TWP, Warszawa 1996.

Niepetnosprawność a praca w Polsce, Raport Banku Światowego, Warszawa 2000.

Niepetnosprawność i starość, red. M. Halicka, J. Halicki, J. Borowik, Białystok 2016 (= „Pogranicze. Studia społeczne" 28).

North D.C., Zrozumieć przemiany gospodarcze, Wolters Kluwer Business, Warszawa 2014.

Ostrowska A., Niepełnosprawni w społeczeństwie, Warszawa 2014.

Polscy niepełnosprawni. Od kompleksowej diagnozy do nowego modelu polityki społecznej, red. B. Gąciarz, S. Rudnicki, AGH, Kraków 2014.

Poselski projekt ustawy o zmianie ustawy o rehabilitacji zawodowej i społecznej oraz zatrudnieniu osób niepełnosprawnych i niektórych innych ustaw, druk sejmowy nr 3292, Sejm VI kad., http://orka.sejm. gov.pl/proc6.nsf/opisy/3292.htm (dostęp: 12.05.2017).

Projekt ustawy o zmianie ustawy o pomocy społecznej, ustawy o planowaniu rodziny, ochronie płodu ludzkiego i warunkach dopuszczalności przerywania ciąży, ustawy o rehabilitacji zawodowej i społecznej oraz zatrudnianiu osób niepełnosprawnych, druk sejmowy nr 66, Sejm IV kad., http://orka.sejm.gov. pl/Druki4ka.nsf/wgdruku/66/\$file/66.pdf (dostęp: 11.05.2017).

Projekt ustawy o zmianie ustawy o rehabilitacji zawodowej i społecznej oraz zatrudnieniu osób niepełnosprawnych, druk sejmowy nr 1330/1999, Sejm III kad., http://orka.sejm.gov.pl/Rejestrd.nsf/wgdruku /1330/\$file/1330.pdf (dostęp: 7.05.2017).

Projekt ustawy o zmianie ustawy o rehabilitacji zawodowej i społecznej oraz zatrudnieniu osób niepełnosprawnych, druk sejmowy nr 1462, s. 32-37, Sejm III kad., http://orka.sejm.gov.pl/Rejestrd.nsf/ wgdruku/1462/\$file/1462.pdf (dostęp: 11.05.2017).

Projekt ustawy o zmianie ustawy o rehabilitacji zawodowej i społecznej oraz zatrudnieniu osób niepełnosprawnych, druk sejmowy nr 1669, Sejm III kad., http:/orka.sejm.gov.pl/Rejestrd.nsf/wgdruku/1669/\$file/1669.pdf (dostęp: 11.05.2017).

Projekt ustawy o zmianie ustawy o rehabilitacji zawodowej i społecznej oraz zatrudnieniu osób niepełnosprawnych, druk sejmowy nr 2264, Sejm III kad., http://orka.sejm.gov.pl/Rejestrd.nsf/wgdruku /2264/\$file/2264.pdf (dostęp: 11.05.2017).

Raport z badań dotyczących zatrudnienia i sytuacji ekonomicznej w zakładach pracy chronionej w roku 1997, PFRON, Warszawa 1998.

Rozporządzenie Komisji (WE) nr 2204/2002 z dnia 5 grudnia 2002 r. w sprawie stosowania art. 87 i 88 Traktatu WE w odniesieniu do pomocy państwa w zakresie zatrudnienia.

Rozporządzenie Komisji (WE) nr 800/2008 z dnia 6 sierpnia 2008 r. uznające niektóre rodzaje pomocy za zgodne ze wspólnym rynkiem w zastosowaniu art. 87 i 88 Traktatu (ogólne rozporządzenie w sprawie wyłączeń blokowych).

Rozporządzenie Rady (WE) nr 994/98 z dnia 7 maja 1998 r. dotyczące stosowania art. 92 i 93 Traktatu ustanawiającego Wspólnotę Europejską do niektórych kategorii horyzontalnej pomocy państwa.

Rozporządzenie Rady Ministrów z dnia 5 maja 1967 r. w sprawie planowego zatrudniania inwalidów, Dz.U. z 1967, nr 20, poz. 88.

Rządowy projekt ustawy o zmianie ustawy o rehabilitacji zawodowej i społecznej oraz zatrudnieniu osób niepełnosprawnych, druk sejmowy nr 2292, s. 13, Sejm IV kad., http://orka.sejm.gov.pl/Druki4ka.nsf (dostęp: 12.05.2017).

Rządowy projekt ustawy o zmianie ustawy o rehabilitacji zawodowej i społecznej oraz zatrudnieniu osób niepełnosprawnych oraz ustawy o podatku od towarów i usług i ustawy o podatku dochodowym, druk sejmowy nr 1462 i 1462A, Sejm III kad., http://orka.sejm.gov.pl/proc3.nsf/0/3BD262AD568B26A3C1257456004D47AA?OpenDocument (dostęp: 12.05.2017).

Skiba W., Wplyw instytucji pomocy publicznej na instrumenty polityki społecznej w obszarze aktywizacji zawodowej osób niepetnosprawnych, [w:] Instytucje w teorii i praktyce, red. B. Borkowska, Wrocław 2015, s. 213-237. 
Skiba W., Wsparcie dla osób niepetnosprawnych w powiatowych strategiach rozwiązywania problemów społecznych: efektywna pomoc w rehabilitacji, czy przypadkowo dobrane działania?, [w:] Niepetnosprawność i starość, red. M. Halicka, J. Halicki, J. Borowik, Białystok 2016, s. 117-135 (= „Pogranicze. Studia społeczne" 28).

Uchwała Rady Ministrów z 13 grudnia 1973 w sprawie zapewnienia warunków dalszego rozwoju spółdzielczości inwalidów, M.P. z 1973, nr 56, poz. 314.

Układ Europejski ustanawiający stowarzyszenie między Rzecząpospolitą Polską, z jednej strony, a Wspólnotami Europejskimi i ich Państwami Członkowskimi, z drugiej strony, Dz.U. z 1994, nr 11, poz. 38.

Ustawa z dnia 9 maja 1991 r. o zatrudnieniu i rehabilitacji zawodowej osób niepełnosprawnych, Dz.U. z 1991, nr 46, poz. 201.

Ustawa z dnia 27 sierpnia 1997 r. o rehabilitacji zawodowej i społecznej oraz zatrudnianiu osób niepełnosprawnych, Dz.U. z 1997, nr 123, poz. 776.

Ustawa z dnia 30 czerwca 2000 r. o warunkach dopuszczalności i nadzorowaniu pomocy publicznej dla przedsiębiorców, Dz.U. z 2000, nr 60, poz. 704.

Ustawa z dnia 27 lipca 2002 r. o warunkach dopuszczalności i nadzorowaniu pomocy publicznej dla przedsiębiorców, Dz.U. z 2002, nr 141, poz. 1177.

Ustawa z dnia 20 grudnia 2002 r. o zmianie ustawy o rehabilitacji zawodowej i społecznej oraz zatrudnianiu osób niepełnosprawnych oraz o zmianie niektórych innych ustaw, Dz.U. z 2003, nr 7, poz. 79.

Ustawa z dnia 21 listopada 2008 r. o zmianie ustawy o rehabilitacji zawodowej i społecznej oraz zatrudnianiu osób niepełnosprawnych, ustawy o podatkach i opłatach lokalnych oraz ustawy o bezpieczeństwie żywności i żywienia, Dz.U. z 2008, nr 223, poz. 1463.

Ustawa z dnia 3 grudnia 2010 r. o wdrożeniu niektórych przepisów Unii Europejskiej w zakresie równego traktowania, Dz.U. z 2010, nr 254, poz. 1700; z 2013, poz. 675; z 2015, poz. 1268; z 2016, poz. 691.

Ustawa z dnia 15 czerwca 2012 r. o ratyfikacji Konwencji o prawach osób niepełnosprawnych, sporządzonej w Nowym Jorku dnia 13 grudnia 2006 r., Dz.U. z 2012, poz. 882.

Wliński M., Modele niepetnosprawności: indywidualny - funkcjonalny - społeczny, [w:] A. Brzezińska, R. Kaczan, K. Smoczyńska, Diagnoza potrzeb i modele pomocy dla osób z ograniczeniami sprawności, Wyd. Nauk. Scholar, Warszawa 2010, s. 50-56.

Zakłady Aktywności Zawodowej. Raport z badania, Warszawa 2009.

\section{Reasons and effects of changes in Polish social policy towards people with disabilities between 1991 and 2017}

Keywords: social policy, people with disabilities, social change, social problems, institutional efficiency

\section{Summary}

This article attempts to identify the causes of key changes in Polish social policy towards people with disabilities. The analysis covers the period since the beginning of the political transformation to the present. The author, on the basis of an analysis of changes in the law, presents a typology of the causes of change and discusses the extent to which they have responded to the policy challenges in this area. 